\title{
22. The importance of surrounding communities in identity formation within afrofuturistic context ${ }^{1}$
}

Tuğba AKMAN KAPLAN²

APA: Akman Kaplan, T. (2021) The importance of surrounding communities in identity formation within afrofuturistic context. RumeliDE Dil ve Edebiyat Araştırmaları Dergisi, (0̈9), 261-275. DOI: 10.29000/rumelide.984761.

\begin{abstract}
Afrofuturism is one of the less known areas of study in terms of African American literature. Even though the term was coined by Mark Dery at the beginning of the twenty-first century, the examples of the movement can be seen much earlier. Its direct colonial roots and political aspects differentiate Afrofuturism from science fiction and fantasy. Octavia Butler's Kindred (1979) is accepted as one of the key texts of early Afrofuturism. The novel demonstrates the ways Butler creates alternative areas especially for African American women and highlights the importance of the protagonist's survival depending on the survival of her respective community. Instead of idealizing the slave community, Butler describes a realistic slave community that is rich in diversity. In the forced situations, Dana discovers the need of her community in the essence for surviving in the past and reaching to a realization about herself. This article analyzes how-with the help of the surrounding communities of antebellum slave community-the main character develops an autonomous identity that helps her to accept her fragmented self to decolonize her mind as well as to have wider understanding of her African American roots. The analysis benefits from Frantz Fanon's thoughts on colonialism and emphasis on the doublevoicedness of African Americans to create a discussion on the effects of surrounding communities on African American characters' decolonization process.
\end{abstract}

Keywords: Afrofuturism, surrounding communities, Frantz Fanon, Octavia Butler, Kindred, decolonization, postcolonial

\section{Afrofütüristik bağlam içerisinde çevreleyen toplumların kimlik oluşumundaki önemi}

\section{Öz}

Afrofütürizm, African Amerikan literatürü içerisinde daha az araştırılmış bir çalışma alanıdır. Her ne kadar Afrofütürizm terimi yirmi birinci yüzyılın başlarında Mark Dery tarafından literatüre eklenmiş olsa da örneklerine çok daha erken rastlanılmaktadır. Direkt kolonyal köklere sahip olması ve siyasi yönleri, Afrofütürizmi bilim kurgu ve fantazi türlerinden ayırmaktadır. Octavia Butler'ın Kindred (1979) romanı erken Afrofütürizmin önemli eserlerinden biri olarak kabul edilir. Roman, Butler’ın özellikle Afrikan Amerikan kadınlar için oluşturduğu alanlara ve ana karakterin hayatta kalma mücadelesinde karakterleri çevreleyen toplumların önemine vurgu yapmaktadır. Köle toplumlarını idealize etmek yerine, Butler realistik bir bakış açısıyla farklılıklara vurgu yapan toplumlar tasvir etmektedir. Zorlu durumlarda ana karakter Dana kendisini çevreleyen toplumların geçmişe yolculuğunda hayatta kalmasına ve kendisini gerçekleştirmesine yardım ettiğini keşfeder. Bu makale, iç savaş öncesindeki ana

This article is composed with the information taken from my $\mathrm{PhD}$ dissertation titled "Alternative Spaces, Identity, And Language in The Proto- And Afrofuturist Writing of Zora Neale Hurston, Ralph Ellison, and Octavia Butler"

2 Assist. Prof., Istanbul Gelisim University, American Culture and Literature, (İstanbul, Türkiye), tugbakman@gmail.com, ORCID ID: 0000-0002-0766-792X, [Araştırma makalesi, Makale kayıt tarihi: 26.07.2021-kabul tarihi: 20.08.2021; DOI: $10.29000 /$ rumelide.984761]

RumeliDE Dil ve Edebiyat Araştırmaları Dergisi Osmanağa Mahallesi, Mürver Çiçeği Sokak, No:14/8 Kadıköy - ISTANBUL / TÜRKIYE 34714 e-posta: editor@rumelide.com tel: +90 $5057958124,+902167730616$
Address

RumeliDE Journal of Language and Literature Studies

Osmanağa Mahallesi, Mürver Çiçeği Sokak, No:14/8

Kadıköy - ISTANBUL / TURKEY 34714

e-mail: editor@rumelide.com

phone: +90 5057958124, +90 2167730616 
karakteri çevreleyen köle topluluklarının ana karakterin otonom bir kimlik oluşturmasında, parçalanmış kimliğini kabul etmesinde ve zihnini dekolonize etmesindeki önemini vurgulamaktadır. Analiz, Frantz Fanon'un kolonyalizm ve Afrikan Amerikalıların çift-seslilik konseptleri üzerindeki düşüncelerinden faydalanarak karakterleri çevreleyen toplumların Afrikan Amerikan karakterlerin dekolonizasyon süreci hakkında tartışma oluşturmaktadır.

Anahtar kelimeler: Afrofütürizm, çevreleyen toplumlar, Frantz Fanon, Octavia Butler, Kindred, dekolonizasyon, postkolonyal

In Black Skin, White Masks, Frantz Fanon uses psychoanalysis to form his arguments and readings on the impact of eagerness towards anti-African American racism as well as stressing on the gender aspect of how power and individualism is generated within colonialism. His thoughts on colonialism and emphasis on the double-voicedness of African Americans had crucial and controversial impact on the area of African American literature. One of the significant aspects that he focused on included the surrounding environment and communities of African Americans and their colonization. Starting off along similar lines, Afrofuturism also focuses on the surrounding communities' importance in terms of decolonization and survival of African American individuals' minds and bodies. As one of the key texts of Afrofuturism, Octavia Butler's Kindred demonstrates how Afrofuturists believe in the cruciality of surrounding communities in decolonization of the individual's both mental and physical self. Butler's novel asserts the ways she creates for African American women and highlights the importance of the protagonist Dana's survival depending on her respective community. In the forced situations, Dana discovers the need of her community in the essence for surviving in the past and reaching to a realization about herself. Throughout the narrative, Dana acknowledges the significant place of community in survival and how that communal involvement enables people to develop as individuals. The use of surrounding communities to create alternative possibilities that help the protagonist to decolonize her mind is among the central focuses of the narrative.

Following her involuntary time travelling to the antebellum South from 1970s, Dana cannot avoid violence even with the prior knowledge from the future. Thus, she takes refuge among the slave community within Weylin plantation. In her first encounter with Alice, who is her great-grandmother in reality, she believes that Dana can take "refuge" (Butler, 2003: 37) in Weylins' plantation. According to Angela Davis, "if resistance was an organic ingredient of slave life, it had to be directly nurtured by the social organization that the slaves themselves improvised" (1995: 204). Butler's positioning Dana in the antebellum South creates an alternative space where Dana experiences a type of oppression that she would not be able to in her own time. Experiencing such oppression helps her to develop a resistance that she would not normally be able to develop if she had not experienced such spaces. Surrounding slave community that eventually becomes like an adopted family as well as her refuge from the realities of slavery plays a crucial part within the development of her resistance. In a moment of despair, Dana states:

\begin{abstract}
Sarah and Carrie were alone when I went in [the cookhouse], and I was glad of that. Sometimes old people and children lounged there, or house servants or even field hands stealing a few moments of leisure. I liked to listen to them talk sometimes and fight my way through their accents to find out more about how they survived lives of slavery. Without knowing it, they prepared me to survive. But now I wanted only Sarah and Carrie. I could say what I felt around them, and it wouldn't get back to either of the Weylins. (Butler, 2003:94)
\end{abstract}

It is important to emphasize that Dana can find solace only among some of the members of the community. Butler does not try to romanticize the communal relationships among the slave community. She portrays all dimensions of the antebellum South from the African American perspective and adds Dana's prior knowledge from the future to equip her with the necessary tools for resistance and survival. As the places

$$
\begin{aligned}
& \begin{array}{r|l}
\text { Adres } & \text { Address } \\
\text { RumeliDE Dil ve Edebiyat Araştırmaları Dergisi } & \text { RumeliDE Journal of Language and Literature Studies }
\end{array} \\
& \text { Osmanağa Mahallesi, Mürver Çiçeği Sokak, No:14/8 } \quad \text { Osmanağa Mahallesi, Mürver Çiçeği Sokak, No:14/8 } \\
& \text { Kadıköy - İSTANBUL / TÜRKIYE } 34714 \text { Kadıköy - ISTANBUL / TURKEY } 34714 \\
& \text { e-posta: editor@rumelide.com e-mail: editor@rumelide.com } \\
& \text { tel: +90 505 7958124, +90 } 2167730616 \text { phone: +90 505 7958124, +90 } 2167730616
\end{aligned}
$$


of the birth of resistance, Butler emphasizes on the ideas of resistance that stem and the collectivity that is visible among the slave community. Butler's main aim at placing Dana in such violent situations may occur from the desire to visualize and evaluate the emotional growth of the protagonist from the beginning until the end. This way, the writer can assign significant roles to the African American characters within the novel.

Frantz Fanon deeply valued and described the colonized individuals as insurgent sources of power. His concentration on resistance of the common people even under great forms of colonial domination is valued among many racially marginalized groups along with Afrofuturists. In the Introduction to Black Skin, White Masks, Fanon asserts:

There is a zone of nonbeing, an extraordinarily sterile and arid region, an utterly naked declivity where an authentic upheaval can be born. In most cases, the black man lacks the advantage of being able to accomplish this descent into a real hell. (2008:2)

In the passages, Fanon criticizes not the black man, but rather he criticizes the black man's relation to the white man. He criticizes the blacks' internalization of this relation in between for the hope to be in equal terms with the whites. He does not evaluate the zone in negative terms. On the contrary, Fanon sees the zone projecting on the subject as "a yes that vibrates to cosmic harmonies" (Ibid.). Dana breaks away from this desire when she replies to Rufus' assault with her knife and endangers her whole being in her final time travelling episode towards the end. Thus, she dives into the zone of nonbeing and "descent[s] into a real hell" that blacks fail to enter. Dana's journey becomes the path of a transitive search toward understanding one's self, identity as well as the past. When Dana says "Pain dragged me back to consciousness" (Butler, 2003: 43), she discloses that in order to arrive at the point of self-understanding and the necessary knowledge, one needs to overcome and survive the challenges and obstacles along the journey.

Another reason for Butler to place Dana in such brutal situations is to emphasize the significance of not forgetting and reevaluating the past histories not only individually but also communally. Even though Dana is the protagonist, the other characters also play crucial roles and assume essential places within the narrative especially in the revisiting of the past. This aspect of the novel leads to Butler's focus on the significance of the community in survival and understanding the self. The surrounding community in the past also includes Dana's distant relatives including her great-grandfather and the slave owner, Rufus, and her great-grandmother and supposedly a free slave, Alice. When she questions her reasons for travelling the past involuntarily, she asserts: "Was that why I was here? Not only to insure the survival of one accidentprone small boy, but to insure my family's survival, my own birth" (Ibid., 29). She realizes that she needs to survive in order to assure the survival of Rufus, her entire familial line from her mother's side as well as her very own existence. Within this difficult journey, her surrounding community-besides her blood relatives-helps her to achieve her goal of survival. By encountering and working with the other African American slaves in the plantation, Dana becomes aware of a different kind of community that eventually helps her to find the necessary strength to continue experiencing her violent journey that includes physical and mental oppression and return back to her home in the present time.

Alice's sufferings that include sexual abuse and physical violence originate because of Rufus' affection for her. In the course of the narrative, this enables Dana and Alice to form a special bond. Dana comments on the issue as "there was no shame in raping a black woman, but there could be shame in loving one" (Ibid., 124). When Alice and her husband, Isaac, decide to run away together Rufus releases the dogs that almost kill Isaac and capture Alice. When she arrives home in a wagon, she is "bloody, filthy, and barely alive" due to the attack (Ibid., 146). Dana becomes as a substitute mother for Alice while healing her and even Alice calls Dana "Mama" (Ibid., 153) at some point. As Alice gets well with the help of Dana's care, she also begins

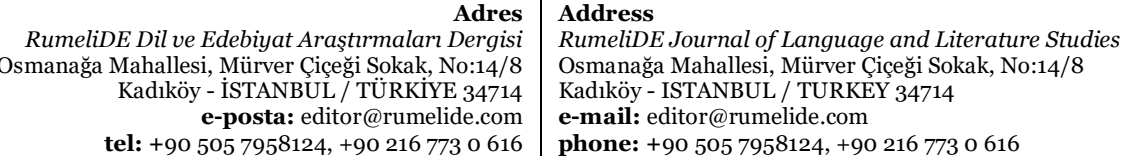


to question and remember what had happened to her and Isaac. As a former free African American, it is even more difficult for Alice to accept and adjust to her new state of enslavement. Alice begins to accuse Dana because she helped her heal and did not tell her the truth sooner: "Doctor-nigger,' she said with contempt. 'Think you know so much. Reading-nigger. White-nigger! Why didn't you know enough to let me die?"' (Ibid., 160). Since Dana and Rufus' relationship has not been witnessed before, her status among the community bears controversial ideas. To Alice, Dana is more white than African American: "You always try to act so white. White nigger, turning against your own people" (Ibid., 165). Alice's accusation mainly originates from her personal negative feelings toward Dana. In the article titled "Exorcizing the Past: The Slave Narrative as Historical Fantasy," Sarah Wood argues against Alice and writes: "Dana does not meekly accept the position prescribed for her by slavery" (2007: 89). It seems that Dana tries to apply her knowledge from the future for not only her sake but also for the African American slave community's sake instead of trying to assume a white identity. Alice also realizes her unfair treatment of Dana and admits: "I get so mad I can taste it in my mouth. And you're the only one I can take it out on-the only one I can hurt and not be hurt back" (Butler, 2003: 168). Their connection develops even further when Alice shows Dana her letters that Rufus allegedly sent to Kevin, who is her husband stuck in the past and did not know that Dana had travelled back to the past to reach him. Upon finding out Alice's suicide in her final episode, Sarah describes them as sister-like: "You sure fought like sisters... Always fussin' at each other, stompin' away from each other, comin' back. Right after you left, she knocked the devil out of a field who was runnin' you down" (Ibid., 250). The novel emphasizes the significance of the assistance among the African Americans. Butler also underscores that this spiritual female bonding also acts as a means for a survival mechanism.

In Black Skin, White Masks, Fanon discusses that black people are fixated in their blackness while white people are fixated on their whiteness. He asserts that the fixation on whiteness generates the fixation on blackness. This reduces black subjectivity into their race. Fanon believes that colonialism is a completed project that affects an individual's life entirely. In order to stray away from its effects, he stresses on the importance of recognition which also justifies African American subjectivity and, therefore, humanity. In Kindred, just like Fanon, Butler draws clear lines between white and black. In the novel, Rufus is fixated on his whiteness and views the world and the African Americans accordingly. Rufus Weylin possesses the same type of aggression and narcissistic behaviors that are described in Freud's uncanny especially towards Alice and Dana that look very similar in appearance but very different in reality. Rufus is used to getting what he wants without the consequences. On the other hand, Alice and Dana pay the price from the both sides. Alice, for example, receives hostile treatment from the fellow African Americans in the plantation as a result of her involuntary connection with Rufus. Dana also becomes a subject of the same treatment because she is assumed to take a submissive role:

I went into the cookhouse and the young man who had his mouth open to speak closed it quickly, looking at me with open hostility. The old man simply turned his back. I'd seen slaves do that to Alice. I hadn't noticed them doing it to me before. Suddenly, the cookhouse was no more comfortable than Alice's cabin had been. It might have been different if Sarah or Carrie had been there, but they weren't. I left the cookhouse and went back toward the main house, feeling lonely. (Butler, 2003: 220)

The African American slaves exclude both Dana and Alice because of the connection they have formed with Rufus.

In her book about African American women slaves in the southern plantations, Deborah White also emphasizes that even though the relationship between African American women was mainly structured on gender bonding and collaboration, "female-to-female conflict" (1985: 133) among the women slaves were also visible. The narrative describes a female betrayal among the slave community when Liza informed Tom

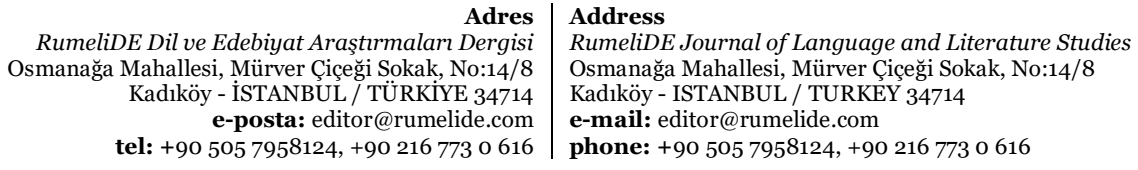


Weylin on Dana's escape. However, this betrayal has some consequences among the community. Missy Dehn Kubitschek argues that "Kindred does not romanticize the solidarity of the slave community" (1991: 31). Alice, Tess, and Carrie punish Liza for what she has done to their surrogate sister. The passage about Liza's betrayal in the novel constitutes the realistic aspect of the internal divisions among the African American slave communities in the antebellum South. It is not Butler's aim of demonstrating an idealized version of the slave community, instead, she reveals the complex structuring and dynamics of the African American slave community that includes cultural, economic and speculative aspects.

The special connection between Alice and Dana is not only felt by themselves but also felt by the others around them as well. However, Rufus' interconnection between the two women is described more than just believing it to be a resemblance. For instance, when Rufus cannot find either of them around, he keeps searching and when he finds them together, he is satisfied: "Behold the woman [...] You really are only one woman. Did you know that?" (Butler, 2003: 228). Alice's reaction to Rufus' comment is much more concerned. She says: "I know what he means. He likes me in bed, and you out of bed, and you and I look alike if you can believe what people say [...] [A]ll that means we're two halves of the same woman-at least in his crazy head" (Ibid.). This passage also foreshadows the last encounter of Dana and Rufus. His obsession comes to a point that Rufus does not hesitate to attempt to rape Dana. Dana has no choice but to stab him in order to resist his assault. The consequence of Dana's resistance leads her to lose an arm while traveling back to the present for the last time. Dana's marked body signifies the African Americans' buried history. Dana's loss also shows that the cultural trauma caused by the colonial oppression of slavery still exists within the generations who did not experience slavery directly. Losing her arm after the final episode cannot be compared to the changes in her existing conscious experiences throughout the novel, as if the novel stands as a warning of the consequences one needs to face as the price of forgetting one's past history. At the end, Dana possesses a memory that cannot be forgotten mainly because of the marks it has left on her body.

In Black Skin, White Masks, Fanon argues:

Since [the white man's] ideal is infinite virility is there not a phenomenon of diminution in relation to the Negro, who is viewed as a penis symbol? [...] Is the Negro's superiority real? Everyone knows it is not. But the prelogical thought of the phobic has decided that such is the case. (2008: 123)

According to Fanon, the African Americans encounter themselves as phobic objects to the extent that they think and act subjectively as whites do. Similarly, Susan Bordo focuses on the surrounding forces that stem from society and how they affect the body and how these forces differ over time and between societies/cultures. She describes the body as a "text of culture" (1995: 165) and argues that already established cultural norms are engraved in the body in the forms of physical appearance and activities. One of the most prominent examples of such activities occurs when Dana sees "the small slave children who chased each other and shouted and didn't understand yet that they were slaves" (Butler, 2003: 76). During her trip with Kevin, Dana experiences the anxiety of seeing slave children acting out their mother's worst fears as a game without realizing the reality behind it:

"Now here a likely wench," called the boy on the stump. He gestured toward the girl who stood slightly behind him. "She cook and wash and iron. Come here, gal. Let the folks see you." He drew the girl up beside him. "She young and strong," he continued. "She worth plenty money. Two hundred dollars. Who bid two hundred dollars?"

The little girl turned to frown at him. "I'm worth more than two hundred dollars, Sammy!" she protested. "You sold Martha for five hundred dollars!"

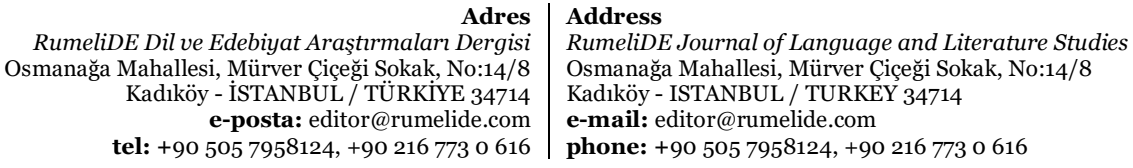

RumeliDE Dil ve Edebiyat Araşttrmaları Dergisi tel: +90 $5057958124,+902167730616$
Address

Osmanağa Mahallesi, Mürver Ciceği Sokak, No:14/8

e-mail: editor@rumelide.com

phone: +90 $5057958124,+902167730616$ 
"You shut your mouth," said the boy. "You ain't supposed to say nothing. When Marse Tom bought Mama and me, we didn't say nothing." (Ibid., 99)

Dana leaves the space immediately "feeling tired and disgusted" (Ibid.). The example also demonstrates an act of doubling. In the novel, the doubling usually occurs between Dana and Alice as an expression of desire. Alice and Dana's physical appearances are very similar to each other to a point that most people mistake them as sisters. Through Alice, Dana confronts a life in the past that she could have had. Even though she is portrayed as a free African American at the beginning of the novel, this status proved to be no use to Alice. Throughout her life, Alice experiences the brutal sides of slavery firstly with the selling of her father, then her husband. Afterwards, she is forcefully taken as a possession by Rufus and finally her children are sold into slavery-at least that is what she believed. Dana takes part in every part of Alice's life as she is trying to survive in the antebellum South. Dana also chooses to believe that she can have a positive impact on Rufus that will lead to an overall character and mind change. But later in the narrative, she finally realizes that whatever she does, Dana will not be able to change Rufus and he will do what it takes to keep Dana connected to him in the past. He is aware of his leverage on Dana and does not hesitate to use it. By repeatedly saving Rufus' life, Dana actually helps to pave the way for Alice's rape, which will eventually lead to Dana's existence. The conundrums Butler creates in the novel demonstrates the complexity of race relations as well as survival.

In the antebellum South, the African American slave community tries many different methods to survive. These resistance methods also include black non-resistance to colonial oppression among the whole race. Octavia Butler processes this notion on connecting Dana's and her ancestors' entire existence on the rape of Alice. Dana chooses survival over her ancestor's rape. Thus, the author demonstrates another perspective of the effects of racial oppression on the oppressed ones. However, Dana's will to survive leads to Alice's death since after the last removal of her humanity through her children, Alice commits suicide by hanging herself. This is an example of uncanny including separation and doubling. Alice's suicide is an example of a mother being forcefully separated from her children and in return she separates herself from them at the same time.

Besides her own survival, Dana tries to reassure Alice's survival since she believes that Alice is an exemplary figure to demonstrate Dana how to survive. Dana describes her from her own perspective:

From what I could see of her, she seemed to be about my age, slender like her child, like me, in fact. And like me, she was fine-boned, probably not as strong as she needed to be to survive this era. But she was surviving, however painfully. Maybe she would help me learn how. (Butler, 2003: 38)

From Dana's description and Rufus' special interest in Dana due to her undeniable resemblance to Alice, it is possible to interpret that Alice is a character that mirrors Dana in the past. Their relationship is special since both women mutually benefit from each other on how to survive the oppression in the past. Dana cannot control what she acquires after she becomes conscious following her time travel episodes but she is able to have control over her own responses to the things she acquires. She feels the responsibility to ensure the survival of herself and the people in her surrounding communities.

In Kindred, the white men in the antebellum South show perseverance when it comes to taking extreme measures towards African Americans. The extreme measures that are taken by the slave-owners are described explicitly in the novel. In one of her episodes, Rufus' father catches Dana teaching one of the younger slaves with books from his library and Dana's only thought is: "It wasn't supposed to happen. For as long as I had been on the plantation, it had not happened -no white had come into the cookhouse" (Ibid., 106). He begins to beat Dana violently until she becomes unconscious and returns back to her present time. Upon

Adres | Address

RumeliDE Dil ve Edebiyat Araşturmalar Dergisi $\quad$ RumeliDE Journal of Language and Literature Studies Osmanağa Mahallesi, Mürver Çiçeği Sokak, No:14/8 $\quad$ Osmanağa Mahallesi, Mürver Çiçeği Sokak, No:14/8 Kadıköy - İSTANBUL / TÜRKIYE 34714 Kadıköy - ISTANBUL / TURKEY 34714 e-posta: editor@rumelide.com e-mail: editor@rumelide.com tel: +90 505 7958124, +90 2167730616 phone: +90 505 7958124, +90 2167730616 
returning back to the antebellum South, Dana learns that her disappearance caused further anger and confusion which led Master Weylin to blame the other slaves and sell some of their family members as a punishment. Butler is aware of the kinship between the colonizer and the colonized, however, she emphasizes on the "horror of miscegenation" (Luckhurst, 1996: 28) that denounces the bond and disrupts the motivation in terms of resistance/survival. The fact is that Rufus' survival instincts forestall his inbuilt oppressive values and he reaches out to Dana and is able to bring her back to the past only when he faces/fears death. In Kindred, body is used as a site of oppression. Butler not only focuses on colonialism's attention on race but also to consider oppression on gender even long before the oppression on race occurs. Butler intentionally lets Dana misinterpret the history and the mutual relationships. Firstly, she is caught on the idea that Weylin should not have been in the cookhouse in the first place because she views the master-slave relationship as occurring only between races. She fails to acknowledge that gender also has an important place in this relationship as well. She evaluates the cookhouse as a feminine space for slaves. She does not realize that masculinist view necessitates surveillance on women.

The cookhouse incident is also significant in terms of Butler's shift of the use of science fiction devices. Marleen S. Barr argues that the figure of an alien other generally connotes an expression of perplexity related to race or gender. She argues that women writers use the figure as a way to reflect their own personal agendas. Barr argues that Dana, along with other female protagonists in similar representations, is

in opposition to science fiction stereotypes about vanquishing aliens, join with or are assisted by the aliens they could be expected to view as epitomizing the very opposite of humanness. These female characters, who are themselves the Other, do not oppose the Other. (1993: 99)

In order to face with the dominant historical memory, these-often feminist-female characters associate themselves with the alien other. After the incident, new modes of historical memory take place.

The novel demonstrates various ways of resistance to slavery and solidarity especially among the female slaves while also emphasizing the restrictions. Butler takes the slave community's active mechanism into consideration and tries to portray it as realistically as possible. Each African American character-male or female-who attempts to resist the system also experiences the consequences of his/her actions. Angela Davis argues that the African American female characters from the past are exhibited as women "transcending, refusing, fighting back, asserting [themselves] over and against terrifying obstacles" (1995: 214). The African American female characters show resistance on their own ways but Dana, Carrie, Sarah, and Tess can be evaluated as survivors while Alice cannot be included in this category because she surrenders to the sexual and racial oppression. Dana-like the others- "is not a victim" (Shinn, 1985: 211). All pay the cost but also help the slave community to be a safer place that can be perceived with an African American woman's presence. Despite the inner divisions among the community, it becomes a space of nourishment and consolidation for Dana.

Butler uses the past to address different possibilities in history and the present in which African American women possess the option to exert some presence, influence, and even power in some situations that they do not possess over the oppressive forces (i.e. the slave owners or the biased white community). By assigning a degree of autonomy, especially to African American females, Butler also empowers them with an assertive voice especially with the help of surrounding communities. In Kindred, along with African American resistance to an oppressive community, African American female agency is present as well. Dana's distress following her first time travelling episode is made evident in her words: "Maybe I'm just like a victim of robbery or rape or something-a victim who survives, but who doesn't feel safe anymore" (Butler, 2003: 17).

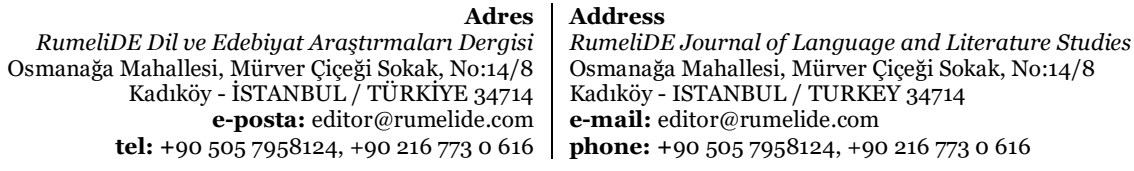


Even though she calls herself a victim, she demonstrates a figure that is much stronger at the end. She eventually fails to deny degradation, however, she continues to resist and help others to resist the oppressive structures of the antebellum South. She constantly tries to figure out new ways to increase her agency throughout the novel whether it is to teach other slaves to become literate or stall Rufus so that Alice would have a head start if she chooses to run away.

In Black Skin, White Masks, Fanon circles around the quote: "Look, a Negro!" (2008: 82) and how it is a form of an insult as a part of anti-African American racism. He regards the word as an insult and the gaze that comes with this declaration as locking one's identity within an anti-African American racist perspective. He believes when the recognition of African Americanness comes, the subjectivity and therefore the humanity of African Americans can also occur. When Rufus calls Dana nigger, she corrects him: "I'm a black woman, Rufe. If you have to call me something other than my name, that's it" (Ibid., 25). At that moment in the narrative, the protagonist becomes a figure for African American women in the plantations and for the sexual and racial abuse they receive. Dana demonstrates resilience above common during her visits to the antebellum South and at the end, manages to survive despite all the hardship she experiences. Barbara Lewis asserts:

Butler crafts a character with dual status, one that steps in and out of the box. Dana is ordered around, made to say master, sent to the fields, whipped, and faces down a gun, twice, but she can read and write, she can nurse and heal the sick, she doesn't age, and, on death's doorstep, she can flee to another time. (2007: 302)

Time travelling enables Dana to resist death and discover the durableness of African American women ancestors. The goal to survive allows Dana to adopt various roles and adapt to the changes in the oppressive structure. Following Dana and Kevin's trip back to the past, she says that they need to adjust themselves to social roles accordingly: "We're going to have to fit in as best we can with the people here for as long as we have to stay. That means we're going to have to play the roles you gave us" (Butler, 2003: 65). In order for both to stay away from trouble, the couple acts out the role of a master and a slave.

While she is performing her act as a slave, she tries to survive using her education, literacy, and autonomous character. At this point, she still believes that she can prevent Rufus from turning into a character like his father. As the narrator, Dana asserts: "I would try to keep friendship with him, maybe plant a few ideas in his mind that would help both me and the people who would be his slaves in the years to come" (Ibid., 68). Using the prior knowledge from where she came from, the protagonist tries to enhance her and the surrounding African American community's position by attempting to change Rufus' character and understanding of the African Americans. However, when she tries to use her prior skills and education, her attempts are met with violence in the majority of the time. In Black Skin, White Masks, Fanon describes the denial of the ones who deny African Americans as individuals. His portrayal on how African Americans see themselves as well as the whites put a new perspective on the general idea that the only valuable perspective was how whites portrayed blacks. Dana thinks that she can educate the other slaves with her literacy skills to help them construct a better life for them. However, the passage following Tom Weylin's discovery of Dana's actions is a violent one:

Weylin dragged me a few feet, then pushed me hard. I fell, knocked myself breathless. I never saw where the whip came from, never even saw the first blow coming. But it came-like a hot iron across my back, burning into me through my light shirt, searing my skin [...] I screamed, convulsed. Weylin struck again and again, until I couldn't have gotten up at gunpoint [...] By then, I almost wanted to die. Anything to stop the pain. (Butler, 2003: 107)

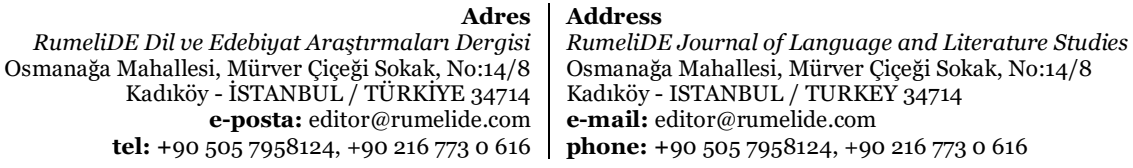

RumeliDE Dil ve Edebiyat Araştırmalar Dergis tel: +90 505 7958124, +902167730616 
When she can no longer endure the pain, she vomits and returns back to her present time. Since pain is the only thing that enables her time travel, she asserts: "Pain had never been a friend to me before, but now it kept me still. It forced reality on me and kept me sane" (Ibid., 113). In a way, the pain proves Dana that history really occurred and her wounds and scars attest to that realization.

Dana always needs to be aware of people's actions and consequences so that she can learn and have some degree of control over her environment since her survival relates to her surrounding community's survival as well. It can be argued that time travelling acts as a catalyst that enables Dana to revisit the past to highlight the main aspects of survival from racial and gender oppression as well as problematic situations. Octavia Butler places Dana in difficult situations to unravel her inner strength and increase her tolerance to violent situations. As the protagonist experiences these situations, she becomes more aware of the places of communal cooperation and association in survival and self-awareness. She acknowledges the significance of being part of a community within survival and how this membership also helps the person to develop herself as an individual entity.

Following how Fanon points out the incompetence of social and experimental terms related to human identity, difference in sexuality, and the connection built on them, while focusing on the basis of both social and historical conditions related to the central structures of subjects, Butler shapes her protagonist according to her experiences in the past. As she begins to spend more time in the antebellum South, Dana experiences the complex slave community dynamics including alienation, exclusion, internal division as well as cooperation and sisterhood. The collaboration and sisterhood were the main elements that help Dana to survive from her experience of racial oppression and gain the necessary agency for her present life. In her review of the novel, Barbara Lewis argues on the female figures:

\begin{abstract}
These slave women did not wage bloodletting rebellions to express outrage at the saddling of their bodies, the theft of their pleasure, or the harnessing of their reproductive organs, but they do what they can to resist on a smaller scale, hitting slavery where it lived and lusted. (2007: 300)
\end{abstract}

Dana, too, realizes that there are more kinds of resistance than physical or verbal confrontation and the women slaves take different approaches to deal with racial oppression. For instance, the house mammy, Sarah encounters Tom Weylin's sexual abuse and as a result she loses all her children except for Carrie because of Margaret Weylin's jealousy. Dana believes that "she has done the safe thing-had accepted a life of slavery because she was afraid. She was the kind of woman who might have been called 'mammy' in some other household" (Butler, 2003: 145). However, underneath her submissive mammy disguise, Sarah fights for her survival in her own way despite all the odds of slavery. "Sarah's creation and maintenance of a relatively safe space for the slave community attests to the complex strategies conceived to resist slavery" (Wood, 2007: 92). In addition to ensuring her survival, Sarah is a substitute mother for the other African American slave community:

In Margaret's absence, Sarah ran the house-and the house servants. She spread the work fairly and managed the house as efficiently as Margaret had, but without much of the tension and strife Margaret generated. She was resented, of course, by slaves who made every effort to avoid jobs they didn't like. But she was also obeyed. (Butler, 2003: 144)

Like a mother, she is sometimes resented by the other slaves, who are ordered to do unwanted jobs, but still respected. She is the one to transform the cookhouse into a solidary place that the other slaves can take refuge in and also to organize the division of labor among the others in order to eliminate any possibilities of physical oppression. When Dana talks about running away from the Weylin plantation, Sarah tells her to be careful and stresses on the consequences that may occur both for Dana and the other slaves in the

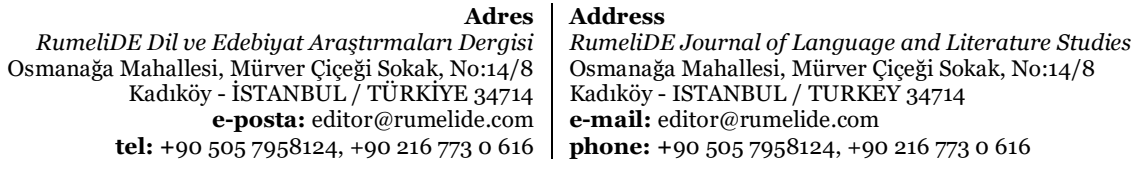


plantation. Through Sarah, Butler emphasizes that resistance does not always have to involve direct confrontation.

Alice is also a prominent character that fights for survival. She is one of the figures who experiences slavery most violently. Through her, Butler tries to confound the stereotypes that present African American women slaves as promiscuous femme fatales. Even though born free, Alice is enslaved because she helps her slave husband run away. Captured by Rufus, she finally acknowledges that she can never be free again. From that point on the narrative, she belongs to Rufus. Alice loses the control of her body as well as her life. It is at this point of the narrative that Dana comes to a fork. She can either help Alice and danger her entire maternal familial line's existence or she can be an accessory of the corrupted system and ensure her and her relatives' existence. It is important to highlight here that even though Dana chooses to collaborate with the system for her survival, she does not force Alice into Rufus' arms. After she recovers her health, Rufus calls Alice to his bed. Alice and Dana have the following conversation:

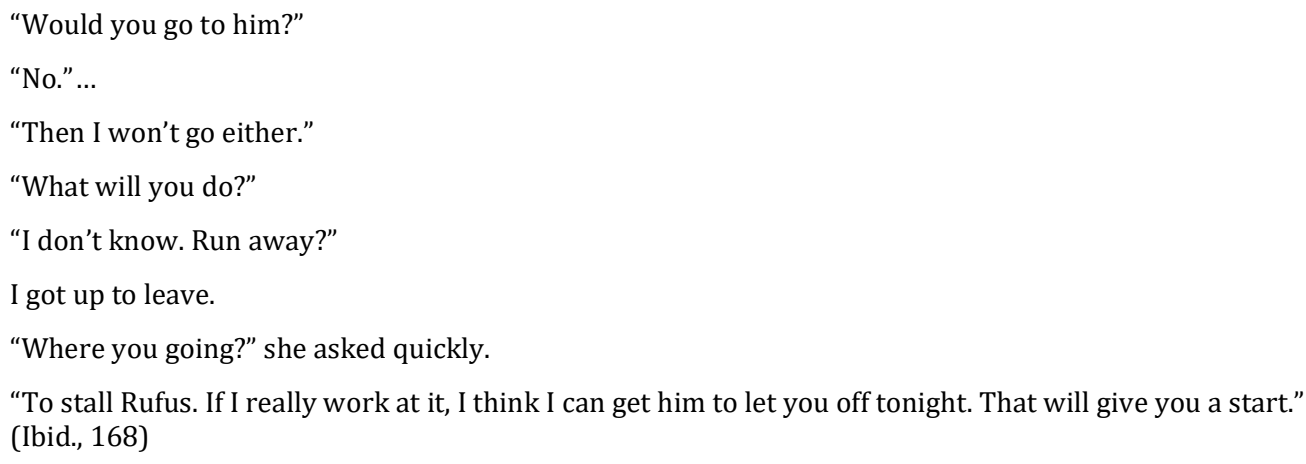

At that moment, Dana risks everything she has worked for to survive in the past and ensure her existence in the future. While healing Alice's wounds, Dana's conscious is aware of what will happen to her after she gets well: "I had helped her to heal. Now I had to help Rufus tear her wounds open again" (Ibid., 165). Still, she realizes that she cannot force Alice into Rufus' bed and be an accomplice to such oppression. At this point in the novel, Dana already tries to break away from the father's law by attempting to endanger her existence and submit to Rufus' order. However, this time Alice accepts her fate and says that she cannot run away anymore. As Alice gives in to Rufus' wishes, she slowly becomes "a quieter more subdued person" (Ibid., 169). After she has children from Rufus, she attempts to run away one last time in order to break free from Rufus' sexual assaults. When Rufus finds out, he tells Alice that he sold Alice's children in the slave market. Upon this news, Alice commits suicide as the final act of resistance. Sarah Wood explains Alice's decision to end her life as "her only possible path of resistance and rebellion" (2007: 94). In the novel, Butler uses the character of Alice to demonstrate the sexual and mental abuse-often excluded from the historical documents-toward African American women slaves.

In the Introduction of Afrofuturism 2.0, Afrofuturist Reynaldo Anderson argues that one of the aspects of Afrofuturism is to question the "possibilities for black female bodies historically represented as quintessentially other, abject, and alien" (2016: xv). The chosen novel also demonstrates the anxiety towards interracial intimacy and marriage as well as the unique alternative space it provides for the protagonist. Butler does not only focus on the enforced sexual involvement between enslaved African American women and white men in the antebellum South, but also demonstrates the difficulties of the novel's present-day interracial couple and the oppositions they receive from the others. The relationship between Dana and Kevin is un conventional not only because their relationship survives after everything they had been through

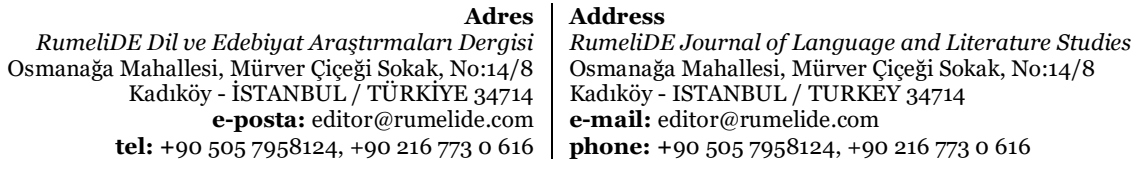


but also their love for one another is depicted as a psychologically healthy relationship that does not generally occur in African American literary works after the Second World War.

Kevin assumes a key role in his wife's survival even when he does not travel with her across time and space. Dana describes him as: "[Kevin] was like me—a kindred spirit crazy enough to keep on trying" (Butler, 2003: 57). Aside from trying to understand what is happening to his wife at the beginning of her travels, Kevin stands by her throughout her journeys back and forth. When they time-travel together, Kevin repeatedly tells her to leave Weylin Plantation for a safer place but Dana believes that it is the safest place for her even though Rufus tries to hinder Dana from going back to her present time. She argues that she is more likely to survive if she stays: "I'll have a better chance of surviving if I stay here now and work on the insurance we talked about. Rufus. He'll be old enough to have some authority when I come again. Old enough to help me. I want him to have as many good memories of me as I can give him now" (Ibid., 83). Dana sees Rufus as insurance because she believes she can change him. As time progresses, Dana realizes that it is not as simple as she believes to be.

At the beginning of the novel, Dana cannot be sure of Kevin's real thoughts and what separates him from the racist coworker, Buzz, who sees African American women as "objects of display" (Collins, 1990: 168). In "Eating the Other," bell hooks argues that a considerable number of white men possess:

The desire to make contact with those bodies deemed Other, with no apparent will to dominate, assuages the guilt of the past, even takes the form of a defiant gesture where one denies accountability and historical connection. Most importantly, it establishes a contemporary narrative where the suffering imposed by structures of domination on those designated Other is deflected by an emphasis on seduction and longing where the desire is not to make the Other over in one's image but to become the Other. (1992: 25)

According to hooks, some whites express desire for African American women not necessarily because they want to express racial domination. Desire reflected on the African American body may stem from both the wish to conciliate the undesirable guilt for an individual's prejudiced acts as well as the prejudiced acts of that individual's white ancestors and the individual's possible future descendants.

The couple's marriage faces opposition from their own families. Prior to their marriage, Dana visits her aunt and uncle while Kevin visits his sister to inform them about their decision to marry. Both families oppose the marriage because of different reasons. Kevin's sister, Carol, opposes due to her racial hatred as well as communal oppression. When explaining his encounter with his sister, Kevin says: "She didn't want to meet you, wouldn't have you in her house—or me either if I married you" (Butler, 2003: 110). By emphasizing that his sister would end her connection with Kevin if he married an African American woman, Kevin demonstrates what is called "rebound racism." After his dialogue with his sister, Kevin begins to question his own self. The uneasiness he feels is reflected to Dana. Heather Dalmage comments on the distress stemming from the rebound racism. People who feel rebound racism tend to exclude themselves from being white while trying to demonstrate themselves as anti-prejudiced. She says:

The lack of available language to describe racial identities outside of the black-white dichotomy coupled with the essentialist thinking that all whites are bad leaves some interracially married whites with no option other than claiming a black identity. This is one way in which individuals contend with and get caught in essentialist language and thought. (2000: 67)

Even though Kevin is not African American, he prefers to perceive the antebellum South from the African American perspective. Contrary to Dana's fears, Kevin chooses to help the African American slaves by providing shelter and guidance for their escape during the five years that he gets stuck in the past without

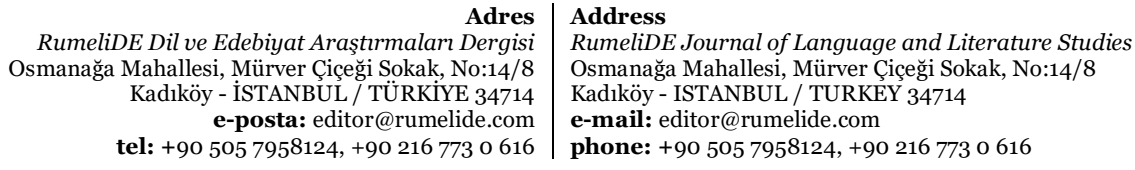


Dana. In Tripping on the Color Line: Black-White Multiracial Families in a Racially Divided World, Heather Dalmage explains the term as prejudice against whites who are intimately involved with other races:

In these cases, racism is directed at the black partner but also affects the white partner [...] The effect can be financial, emotional, or physical. While the white partner is not the intended victim, she or he is in a relationship with someone who is. For example, if the black partner does not get a fair raise, this affects the financial well-being of the white partner. If the black partner is given unfair traffic tickets or treated badly at work, this spills over into the family. The white partner with emotional, financial, and familial ties to the black partner gains a sense of the pain and disadvantage doled out to people of color in a system of whiteness. (Ibid., 63-64)

According to this definition, Kevin experiences rebound racism and, thus, puts some distance between himself and his sister in a way that does not directly put the blame on his sister as a racist individual. $\mathrm{He}$, rather, blames his brother-in-law. He says: "It's as though she was quoting someone else [...] Her husband, probably. Pompous little bastard. I used to try to like him for her sake [...] Her husband would have made a good Nazi. She used to joke about it-though never when he could hear" (Butler, 2003: 110). In a desperate attempt, Kevin tries to shift the negative focus away from his close relative, however, Dana is more realistic on the subject and says: "But she married him" (Ibid.). Kevin, not being ready to accept the truth, ignores Dana's statement and instead tells a story about the time his sister had a high school friend who was African American and overweight like his sister at the time. In Interracial Couples, Intimacy, and Therapy: Crossing Racial Borders, Kyle D. Killian asserts:

\begin{abstract}
Ideologically speaking, 'whiteness' is frequently constructed as a deracialized and monolithic dominant other. Such an ideology tends to subjugate and make invisible both racial and ethnic difference and the ways in which racism operates among whites, not just between whites and persons of color. While race does serve as a potent positioning device among white persons in the majority culture, the functions and influence of race and racism go largely unnoticed by many white people because whiteness is not a selfconscious racial identity or social signifier in most white people's minds. (2013: 116)
\end{abstract}

The novel demonstrates how a white person can encounter problems when connected with an African American person(s). The novel examines the "sociohistorical and political meanings of crossing various borders (racial, class and gender)" (Ibid., 177) and the personal and inherent consequences that are the result of the crossing. By telling this story, it is as if Kevin is trying to exonerate his sister and therefore himself from having prejudiced beliefs. It is easier for him to connect his sister's prejudiced beliefs with her marriage. Kevin associates his sister's behavioral change with the change of her class. After her marriage, he says that she moves to a "big house in La Canada," and begins to recite "cliched bigotry at [Kevin] for wanting to marry [Dana]" (Butler, 2003: 111). Dalmage argues: "For many whites, rebound racism makes them more aware of white privilege" (2000: 66). In the novel, there is no verification whether or not this explains what Kevin goes through, however, it can give an alternative explanation on the anxiety that Kevin experiences due to his interracial marriage. By using the example of his sister and her African American high school friend, he mirrors the complex behavior pattern of the whites who are not able to resolve their inner conflicts since the examples he provides about his sister's friend and her husband are barely connected to each other. The only common ground is the aim of Kevin to exonerate his sister and, thus, himself from having racial prejudice. Kevin does not include that people who are friends or get involved with people from different racial backgrounds can also hold prejudiced beliefs.

During the period of the novel's publishing, which coincides with the post-Civil Rights era, Americans were inclined to amplify the intimate relationships between African American men and white women to a point that "those dynamics [were] seen to determine those relationships" whereas in the case of intimate relationships between white men and African American women, "those same dynamics have tended to be

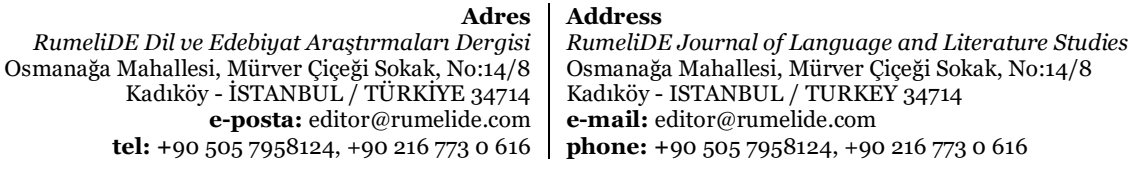


downplayed or suppressed, thereby characterizing such whites as people who are less predisposed to racist beliefs than whites who do not have black acquaintances or intimates" (Foster, 2007: 152). According to this logic, there is a direct correlation between an individual's sexual choice and treatment of the other race. This is problematic in terms of both races. When a white man, who is involved with an African American woman, demonstrates hatred or violence towards other African Americans simply because of their skin color, it is viewed as normal ${ }^{3}$. On the other hand, an African American man who is involved with a white woman is viewed as being not only violent with white men but also psychologically unwell because of his inner inferiority towards white men. So, it is possible to interpret the complexity of Kevin's defense of his sister by linking her with an African American friend she once had with not also his way of exonerating his sister but only himself as well because he is married to an African American.

A similar approach of Carol is also demonstrated by Dana's aunt and uncle. Even though Dana is well aware that they will not take the news well, she still feels uncomfortable after she talks to them. Both of her relatives respond very differently from each other. Her aunt does not protest thinking that their children will have lighter skin and that is good enough reason for her to accept Dana's marriage to Kevin because she believes that Dana is "a little too 'highly visible" (Butler, 2003: 111). Dana's aunt does not fancy white people but "she prefers light-skinned blacks" (Ibid.). On the other hand, the uncle takes the news personally and gets offended. Dana explains her uncle's motive as:

[H]e's my mother's oldest brother, and he was like a father to me even before my mother died because my father died when I was a baby. Now...it's as though I've rejected him. Or at least that's the way he feels. It bothered me, really. He was more hurt than mad. Honestly hurt. I had to get away from him."

"But, he knew you'd marry some day. How could a thing as natural as that be a rejection?"

"I'm marrying you...He wants me to marry someone like him—someone who looks like him. A black man." (Ibid.)

When Kevin makes it clear that he cannot relate to their reasoning, Dana just says that her relatives are old. However, she makes it apparent that her uncle's reaction bothered her. This uneasiness may stem from her evaluation of her uncle's reasons and their accuracy. By simply making a referral to their ages as the answer to their behaviors, she does not provide a detailed reply to Kevin. Dana finds the belief that separates whites and African Americans from forming an intimate relationship as offensive because as a character, she is an individualist. The real reason for Dana's uneasiness may stem from Kevin's negligence to the functioning of racism in the United States.

Even though both Dana and Kevin are occasionally exposed to racist remarks by a coworker who is constantly drunk, their relationship is mainly accepted by the surrounding community in 1976. However, neither of the families of the couple welcomes their union. As an option, Kevin suggests Dana to " $g$ o to Vegas and pretend [they] haven't got relatives" (Ibid., 112). Following Dana's time travels, the statement becomes ironical since she cannot pretend this without risking her own existence. Through the character of Kevin, the novel mirrors the deviation and the dilemmas that are produced by whites. Dana warns him about his sister who may not be reacting well to their interracial marriage, but Kevin does not agree with Dana's opinion and falsely assumes the best of her. He does not want to believe his sister's inability to resist prejudice that is infused to her by her surrounding community. His sister's rejection paves the way for his individual journey to the past when he tries to hold on to Dana while she is pulled back in time but ends up 
travelling back with her to the antebellum South. In order to protect Dana, Kevin needs to collaborate with the surrounding community of the South.

Besides concerns, Kevin demonstrates explicit anxiety about Dana's travels to the past. It can be inferred from the novel that Kevin's anxiety stems from his fear that Dana will no longer be able to distinguish between the two due to her ferocious experiences in the antebellum South. Somewhat similar anxiety is also present in Dana. After the trip in which Kevin accompanies her, she says: "I didn't want him here [...] I didn't want this place to touch him except through me" (Ibid., 59). She is afraid that his experiences in the past would "endanger" him in such ways that Dana "didn't want to talk to him." The narrator explains:

If he was stranded here for years, some part of this place would rub off on him. No large part, I knew. But if he survived here, it would be because he managed to tolerate the life here [...] The place, the time would either kill him outright or mark him somehow. I didn't like either possibility. (Ibid., 77-78)

Dana is against all odds that may have any negative impact on their relationship. She does not know how to behave if Kevin is "marked" by any nineteenth century cultural values that may have changed him into a person more similar to Rufus or any other white men of the period. Her anxiety eases after Kevin and Dana reunite and she is informed that Kevin was working with the Underground Railroad in order to guide the slaves that escape to the North for their freedom. As Fanon asserts different perspectives on how whites and African Americans view one another in Black Skin, White Masks, Butler not only provides different perspectives but also has the protagonist act upon her own perspectives on the whites as well as the slave community of the antebellum South.

From the analysis of the interracial relations in the novel, the anxiety seems to be still present in the US up until the end of the twentieth century. The idea of an interracial couple that was once a thought becomes real in Butler's Kindred but soon it is understood that the uneasiness of the subject still prevails in the beginning of 1980s. The protagonist Dana and Kevin are not able to convince either of their families to accept their union. Their co-worker also presents a similar approach which is a demonstration of the general stance of society towards interracial couples of white and black Americans. In the slave community of the antebellum South, Butler focuses specifically on individual slaves. She focuses on how each of the slaves affects the protagonist's growth closely. Fanon's emphasis on the communal actions towards decolonization has facilitated to view the greater aspect of the novel in terms of African American communities. Through Fanon, the complex modes of thinking of African Americans were accentuated contrary to the general assumption about the shallowness of African Americans in terms of history and thinking.

In Kindred, the African American body including various surrounding communities and interracial relations have been highlighted as enabling the protagonist's decolonization of herself both physically and mentally. The effects of the surrounding communities in this decolonization process are stressed thoroughly. The analysis has stressed upon mainly the positive impacts of the surrounding communities in the Afrofuturistic novel. The slave community in Weylin plantation both help the protagonist find solace and comfort within her own self. She realizes the importance of the surrounding community in survival and decolonization towards the end. The surrounding community empowers the woman protagonist's assertion of her own identity and become more autonomous.

\section{References}

Anderson, R. (2016). Afrofuturism 2.0: The Rise of Astro-Blackness. Eds. by Reynaldo Anderson and Charles E. Jones, New York: Lexington Books.

\begin{tabular}{|c|c|}
\hline Adres & Address \\
\hline RumeliDE Dil ve Edebiyat Araştırmaları Dergisi & RumeliDE Journal of Language and Literature Studies \\
\hline i Sokak, No:14/8 & ıağa Mahallesi, Mürver Çiçeği Sokak, No:14/8 \\
\hline $\begin{array}{r}\text { Kadıköy - İSTANBUL / TÜRKIYE } 34714 \\
\text { e-posta: editor@rumelide.com } \\
\text { tel: +90 } 5057958124,+902167730616\end{array}$ & $\begin{array}{l}\text { - ISTANBUL / TURKEY } 34714 \\
\text { editor@rumelide.com } \\
\text { +90 505 7958124, +90 } 216773 \text { o } 616\end{array}$ \\
\hline
\end{tabular}


Barr, M. S. (1993). Lost in Space: Probing Feminist Science Fiction and Beyond, Chapel Hill: University of North Carolina Press.

Bordo, Susan: "The Body and the Reproduction of Femininity," Unbearable Weight: Feminism, Western Culture, and the Body, 1995, London: University of California Press, pp.165-185.

Butler, O. E. (2003). Kindred, Boston: Beacon Press.

Collins, P. H. (1990). Black Feminist Thought: Knowledge, Consciousness, and the Politics of Empowerment, Boston: Unwin Hyman.

Dalmage, H. (2000). Tripping on the Color Line: Black-White Multiracial Families in a Racially Divided World, New Brunswick: Rutgers University Press.

Davis, A. (1995). "Reflections on the Black Woman's Role in the Community of Slaves," Words of Fire: An Anthology of African-American Feminist Thought, Ed. by Beverly Guy-Sheftall. New York: The New Press.

Fanon, F. (2008). Black Skin, White Masks, Trans. by Charles Lam Markmann, New York, Pluto Press.

Foster, G. M. (2007). Mark: "Do I Look Like Someone You Can Come Home to From Where You May Be Going?": Re-Mapping Interracial Anxiety in Octavia Butler's Kindred, African American Literature, Vol.XXXXI, No:1, pp. 143-163.

Killian, K. D. (2013). Interracial Couples, Intimacy, and Therapy: Crossing Racial Borders, New York: Columbia University Press.

Kubitschek, M. D. (19919. Dehn: Claiming the Heritage: African-American Women Novelists and History, Jackson: University Press of Mississippi.

Lewis, B. (2007). “Antebellum Revisitations: Insurrectionary Interventions in Kindred and Sally's Rape," Revisiting Slave Narratives II, Ed. by Judith Misrahi-Barak. Montpellier, France: Presses Universitaires de la Méditerranée, pp.297-319.

Luckhurst, R. (1996). “'Horror and Beauty in Rare Combination': The Miscegenate Fictions of Octavia Butler," Women: A Cultural Review, Vol.VII, No:1, pp.28-38.

Shinn, T. J. (1985). “The Wise Witches: Black Women Mentors in the Fiction of Octavia E. Butler,” Conjuring: Black Women, Fiction, and Literary Tradition, Eds. By Marjorie Pryse and Hortense J. Spillers. Bloomington: Indiana University Press, pp. 203-215.

White, D. (1985). G.: Ar'n't I a Woman? Female Slaves in the Plantation South, New York: Norton.

Wood, S. (2007). "Exorcizing the Past: The Slave Narrative as Historical Fantasy," Feminist Review, Vol.LXXXV, pp.83-96.

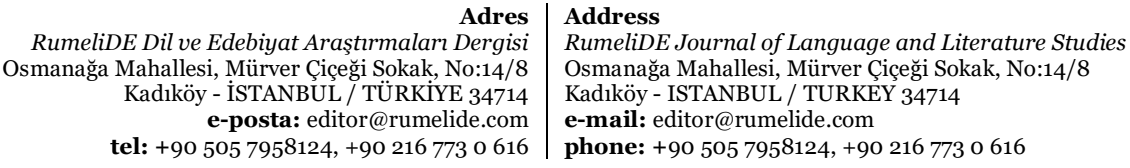

RumeliDE Dil ve Edebiyat Araştırmaları Dergisi tel: +90 505 7958124, +902167730616 